\title{
THE USE OF CLOSE READING TECHNIQUE TO IMPROVE STUDENTS READING COMPREHENSION
}

\author{
Cecep Munawar Payumi ${ }^{1}$, Yayu Fatimah Hartati $^{2}$ \\ ${ }^{1}$ IKIP SILIWANGI \\ ${ }^{2}$ IKIP SILIWANGI \\ ${ }^{1}$ cmpayumi@gmail.com, ${ }^{2}$ ayufa.0919@gmail.com
}

\begin{abstract}
The main pupose of this study is to find out the effectiveness of close reading technique. The research method used is quantitative research, or more specifically the one group pre-test post-test design. The sample of this study is eighth grade students of SMPS PGRI Warungkondang consist of 20 students. Data analysis indicates the mean scores between pre-test and post-test is 22 , the $\mathrm{t}_{\mathrm{obs}}$ is 1.72 with the degrees of freedom (df) 19 and level of significance at 0.05 is 2.59 . Based on data analysis the close reading technique has significant influence to improve students' reading comprehension. Therefore, this technique is considered as a suitable technique for teacher as the strategy for teaching English.
\end{abstract}

Keywords: close reading, reading comprehension, technique.

\section{INTRODUCTION}

English has become an important language that had to be overcome. The English teaching and learning is still dominated by the teacher centered approach. As a product, students' communicative ability is below expectation. Reading is becoming an important need for students to gain knowledge from global information which is most of the used English. However, the important part of reading text is to comprehend the sense of the text itself. As an additional, reading is one things that is performed by a reader to get information from reading content. (Sari, 2014) states "reading is a major point to satisfactory achievement in study because a high percentage of all instruction relies on the students' ability to read." Based on definition above, reading can support students to gain information. Not only information, but also students can learn vocabulary, grammar and punctuation.

Reading comprehension is a text that students use to help them increase their reading skills, by reading it and answering questions be in contact to the text. (Mokhtari, 2016) states "reading comprehension is the irrefutable goal of reading instruction and the very heart of the act of reading." From that definition, it can be summarize that reading comprehension is significant to understandkno some texts. The most of the important things about teaching is there are several reading techniques and the students should be conscious of which technique is mostly match, suspended on the reading task need by the teacher and those techniques has particular affect for its reader.

\section{a. Skimming}

(Kalmane, 2012) argues "skimming or reading for general understanding is skill that involves the finding of key points, the understanding of a gist of a text without going into the details, or in other words, having general comprehension of a text by only previewing it and skipping large unnecessary information pieces."

b. Scanning 
188 Payumi \& Hartati, The Use of Close Reading Technique To Improve Students Reading Comprehension.

(Kalmane, 2012) states "scanning or reading for specific information is skill that involves reading for specific details by almost ignoring the rest of the information in the text and is also related to top-down processing."

c. Intensive Reading

(Kalmane, 2012) has stated that intensive reading as "reading texts closely and carefully with the intention of gaining an understanding of as much detail as possible [...] involving going back over the same (usually short) text a number of times to find more and more in it."

d. Extensive Reading

(Kalmane, 2012) has argued "extensive reading is reading for general understanding, but without such careful attention to the details."

Reading is an activity that has the main purpose to get information from the text that we read. However, reading still has several purposes followed to the reader. (Piankova, 2013), the purposes of reading as follows:

a. By reading we can get information.

b. By reading we can improve our mind.

c. By reading we can enjoy ourselves.

To support students to increase their reading comprehension, it is considered to have technique. Therefore, the teacher should equip students the particular technique or strategy to improve students' reading comprehension. One of them is close reading. Close reading is one of the technique that enable students to increase their comprehension in reading a text. (Brummett, 2010) states "close reading is a mindful, disciplined reading of an object with a view to deeper understanding of its meanings." Moreover, he has stated "close reading is an exercise in linking special knowledge to experience, and theories, methods and techniques are kinds of special knowledge. Theories, methods and techniques give the close reading critic a structure, a discipline, in reading that allows meanings to be detected more powerfully and more efficiently."

Close reading is very important to develop students reading comprehension. (Rief, 2012) argues "close reading is a very interactive process that may involve a variety of strategies, such us discussion with partners or groups; circling unfamiliar words; highlighting important information; and jotting down thoughts, questions, reactions, and connections on sticky notes or in the margins."

(Oczkus, 2014) has stated the steps of close reading as follows:

1) Choose a text

2) Students read silently

3) Teacher read aloud

4) Students reread and discuss with peers

5) Teacher asks text-dependent questions.

Meanwhile, Every technique has their advantages and so do the close reading. These advantages can help teacher to provide students reading strategy and encourage them to read well, close reading also has several advantages for students as well. They are:

1) It allows critics to compare and contrast structures of communication to recognize which elements have been eliminated (Allen, 2017).

2) Close reading is that we are less prone to oversimplification when we talk about either discipline (McLeish, 2014). 
3) It appears an expertise which is untrammelled by specific entrepreneurial interest because it works somewhat opaquely through practice (Alexander Search, 2017).

\section{METHOD}

The writer conducted research design and methodology. (Kaswan, 2016) states that research design is "the architectural plan of a research project. Decision regarding what, where, when, how much, by what means concerning an inquiry or a research study constitute a research design." The writer also used quantitative research method. Moreover, he defines that "quantitative research design is a deductive theory-based research process that focuses primarily on testing theories and specific research hypotheses that consider finding differences and relationships using numeric data and statistical methods to make specific conclusions about phenomena."

Type of the research, the writer uses quasi-experimental design. (Kaswan, 2016) argues "quasi-experimental design, or sometimes called naturally occurring group design, are similar to the true experimental design except that the writer makes comparisons between the means of the scores of the two or more groups that occur naturally." The writer gave the pre-test before the writer did the treatment using the method and gave the post-test after the treatment. To prove this research reliable or not, writer chose the research object as the evidence. (Kaswan, 2016) defines that population as "the entire group of entities or persons to which the result of a study is intended to apply." The writer chose the students of SMPS PGRI Warungkondang, more specifically the eighth grade class as the population. The population in this study was the eighth grade class students of SMPS PGRI Warungkondang in the academic year 2017/2018. In order this research more reliable, writer took the sample for the research. Furthermore, he states "sample is the smaller group which is a portion of a population." The sample of this research was the entire of the population that was eighth grade class. The number of the sample was 20 students.

This study was conducted at SMPS PGRI Warungkondang in eighth grade students of SMPS PGRI Warungkondang in the academic year 2017/2018. The writer started the research on 04 January until 08 February 2018. The research was applied on 6 meetings and the duration for each meeting and test were 45 minutes. In this case, the researcher tried to use one class consists of 20 students at the eighth grade of SMPS PGRI Warungkondang in the academic year 2017/2018.

In this study, the researcher used tests to collect the data, they were pre-test and post-test. The test was given before and after the treatment. The test in this research was multiple choice tests that consisted 20 items of multiple choice questions.

1) Pre-test

Pre-test was used before the treatment to measure how far students could comprehend the text they read and to gain the score as well.

2) Treatment

The treatment in this research used close reading approach. The treatment was given after the pre-test.

3) Post-test

The post-test was used to determine the students' reading skill after giving treatment. The form of the post-test was same as pre-test form. The score of post-test would be compared with the score of pre-test. 
190 Payumi \& Hartati, The Use of Close Reading Technique To Improve Students Reading Comprehension.

To obtain the success of data analysis, writer used several formulas (Kaswan, 2016), they are:

1) Mean Score

The mean is sometimes called arithmetic mean to distinguish it from other forms of mean such as the harmonic mean or geometric mean.

$$
x=\frac{\sum x}{n}
$$

2) Standard Deviation

Standard deviation is the most widely used measure of variability of a set of data in inferential statistical procedures.

$$
\mathrm{SD}=\sqrt{\frac{\Sigma D^{2}-\left(\frac{1}{n}\right)(\Sigma D)^{2}}{n-1}}
$$

3) Degree of Freedom

Degree of freedom is applied to compare between the obtained $t_{\text {obs }}$ with the table entry for relevant degree of freedom and level significant.

$$
\mathrm{df}=\mathrm{n}-1
$$

4) T-test formula

T-test or students' test is a parametric test which is used to discover whether here are statistically significant differences between the means of two groups.

$$
\mathrm{t}=\frac{\bar{x}_{1}-\bar{x}_{2}}{S D}
$$

\section{RESULTS AND DISCUSSION}

\section{Results}

The result of this study was obtained through pre-test and post-test. Pre-test was conducted before the treatment while post-test was performed after the treatment. The result of students' pre-test and post-test as follows: 
Table 1.

Pre-test and Post-test Result

\begin{tabular}{|c|c|c|c|c|c|}
\hline \multirow{2}{*}{ No } & \multirow{2}{*}{ Name } & \multicolumn{4}{|c|}{ Score } \\
\hline & & Pre-test & Post-test & $\Sigma D$ & $\Sigma D^{2}$ \\
\hline 1 & Student 1 & 45 & 90 & 45 & 2025 \\
\hline 2 & Student 2 & 50 & 75 & 25 & 625 \\
\hline 3 & Student 3 & 65 & 80 & 15 & 225 \\
\hline 4 & Student 4 & 55 & 70 & 15 & 225 \\
\hline 5 & Student 5 & 65 & 90 & 25 & 625 \\
\hline 6 & Student 6 & 60 & 70 & 10 & 100 \\
\hline 7 & Student 7 & 65 & 75 & 10 & 100 \\
\hline 8 & Student 8 & 60 & 85 & 25 & 625 \\
\hline 9 & Student 9 & 50 & 80 & 30 & 900 \\
\hline 10 & Student 10 & 55 & 80 & 25 & 625 \\
\hline 11 & Student 11 & 60 & 75 & 15 & 225 \\
\hline 12 & Student 12 & 65 & 85 & 20 & 400 \\
\hline 13 & Student 13 & 45 & 80 & 35 & 1225 \\
\hline 14 & Student 14 & 50 & 70 & 20 & 400 \\
\hline 15 & Student 15 & 60 & 75 & 15 & 225 \\
\hline 16 & Student 16 & 65 & 80 & 15 & 225 \\
\hline 17 & Student 17 & 60 & 85 & 25 & 625 \\
\hline 18 & Student 18 & 60 & 80 & 20 & 400 \\
\hline 19 & Student 19 & 50 & 75 & 25 & 625 \\
\hline 20 & Student 20 & 55 & 80 & 25 & 625 \\
\hline & Total & 1140 & 1580 & 440 & 11050 \\
\hline
\end{tabular}

Based on the data above, the result of score was:

- Mean Score of Pre-test

$$
\begin{aligned}
& x=\frac{\sum x}{n} \\
& x=\frac{1140}{20} \\
& x=57
\end{aligned}
$$

- Mean Score of Post-test

$$
\begin{aligned}
& x=\frac{\sum x}{n} \\
& x=\frac{1580}{20}
\end{aligned}
$$


192 Payumi \& Hartati, The Use of Close Reading Technique To Improve Students Reading Comprehension.

$$
x=79
$$

- Score of Standard Deviation

$$
\begin{aligned}
& \mathrm{SD}=\sqrt{\frac{\Sigma \mathrm{D}^{2}-\left(\frac{1}{n}\right)(\Sigma D)^{2}}{n-1}} \\
& \mathrm{SD}=\sqrt{\frac{11050-\left(\frac{1}{20}\right)(440)^{2}}{20-1}} \\
& \mathrm{SD}=\sqrt{\frac{1370}{19}} \\
& \mathrm{SD}=\sqrt{72.10} \\
& \mathrm{SD}=8.49
\end{aligned}
$$

- T-Test

$$
\begin{aligned}
& \mathrm{t}=\frac{\bar{x}_{1}-\bar{x}_{2}}{S D} \\
& \mathrm{t}=\frac{57-79}{8.49} \\
& \mathrm{t}=2.59
\end{aligned}
$$

The value of t-table with df (degree of freedom) 19 and the level of significance at 0.05 was 1.72. The t-test calculation is 2.59. It can be summed up that $t_{o b s}$ is greater than $t_{\text {table }}$ $(2.59>1.72)$. Its mean that Close Reading is significantly affect in improving students' reading comprehension.

\section{Discussion}

Based on the data analysis above, the writer concluded that close reading approach has affected to students reading comprehension in. the close reading was effective to increase students reading ability as well. It showed from the result of $t_{o b s}$ was greater than the $t$-table $(2.59>1.72)$ and it means that the alternative hypothesis was accepted.

However, this research still has limitation. The sample that writer used in this study only one class. There is no control class in this study as a comparator to make the research become more reliable and valid.

\section{CONCLUSION}

Reading is part of the important skills in English that has to be mastered. However, students still have any trouble to learn English especially in reading skill. To help them in improving that skill, appropriate technique needs to be introduced. One of them is close reading. Based on the result of the research, there is a signifinace result that the close reading technique could improve students' reading comprehension. Therefore, close reading technique is very effective. 


\section{ACKNOWLEDGMENTS}

Alhamdulillahi rabil 'alamin, the writers expresses highest gratitude to Allah Subhanahu wa ta'ala for blessing, love, opportunity, health, and mercy to complete this undergreated research. This graduated research entitled "The Use of Close Reading Technique to Improve Students Reading Comprehension" is submitted as the final requirement in accomplishing undergraduated degree at IKIP Siliwangi Bandung.

In arranging this research, a lot of people have provided motivation, advice, and support for the writers. In this valuable chance, the writers intended to devote his gratitude and respect to all of them. First, the writers deepest appreciation to the parents, the leader of IKIP Siliwangi, to the supervisor who always motivate and support the writers in finishing this research and don't forget, the writers very greatful to have some close friends who always support.

At last, the writers would like to thank everybody who was to important to the successful realization of this undergraduated research. This undergraduated research is far from perfect, but it is expected that it will be useful not only for the writers, but also for the readers. For this reason, constructive thoughtfull suggestion and critics are welcomed. 
194 Payumi \& Hartati, The Use of Close Reading Technique To Improve Students Reading Comprehension.

\section{REFERENCES}

Alexander Search, S. G. (2017) 'Entrepreneurial Literary Theory: A Debate on Research and the Future of Academia'. London: Shot in the Dark.

Allen, M. (2017) 'The SAGE Encyclopedia of Communication Research Methods'. United States of America: SAGE Publication, Inc. doi: 10.4135/9781483381411.

Brummett, B. (2010) 'Techniques of close reading / Barry Brummett'. United States of America: SAGE Publications, Inc. Available at: http://ezproxy.lib.indiana.edu/login?url=http://search.ebscohost.com/login.aspx?direct $=$ true $\& \mathrm{db}=$ cat $00016 \mathrm{a} \& \mathrm{AN}=$ inun $.8594349 \&$ site $=$ eds-live $\&$ scope $=$ site .

Kalmane, R. (2012) 'Improving Reading Comprehension with Online Text Visualization Tools'. New York: Lulu.com, p. 108. Available at: https://books.google.co.in/books?id=lrXRAwAAQBAJ.

Kaswan, D. S. (2016) Research in English Language Education. Revised Ed. Bandung: Putra Praktisi.

McLeish, T. (2014) 'Faith and Wisdom in Science'. United States of America: OUP Oxford, p. 304.

Mokhtari, K. (2016) 'Improving Reading Comprehension through Metacognitive Reading Strategies Instruction'. Lanham, Maryland: Rowman \& Littlefield Publishing Group, Inc.

Oczkus, L. (2014) 'Just the Facts: Close Reading and Comprehension of Informational Text'. Huntington Beach: Shell Educational Publishing, Inc.

Piankova, T. (2013) 'Perfect Compositions'. New York: Lulu.com.

Rief, S. F. (2012) 'How To Reach And Teach Children with ADD / ADHD: Practical Techniques, Strategies, and Interventions'. San Francisco, California: John Wiley \& Sons, $\quad$ p. $464 . \quad$ Available at: https://books.google.com/books?hl=en\&lr=\&id=CbDDylu4pw0C\&pgis=1.

Sari, R. P. (2014) 'THE IMPLEMENTATION OF TEA PARTY STRATEGY IN TEACHING READING OF ANALYTICAL EXPOSITION TO THE ELEVENTH GRADERS', pp. 1-6. 